\title{
Mobile Learning: What Guidelines Should We Produce in the Context of Mobile Learning Implementation in the Conflict Area of the Four Southernmost Provinces of Thailand
}

\author{
Sariya Binsaleh ${ }^{1} \&$ Muazzan Binsaleh ${ }^{1}$ \\ ${ }^{1}$ Prince of Songkla University, Thailand \\ Correspondence: Muazzan Binsaleh, Prince of Songkla University, Thailand. E-mail: \\ bmuazzan@bunga.pn.psu.ac.th
}

Received: June 16, 2013 Accepted: July 24, 2013 Online Published: September 29, 2013

doi:10.5539/ass.v9n13p270 URL: http://dx.doi.org/10.5539/ass.v9n13p270

\begin{abstract}
Existing typical room based learning in the four southernmost provinces of Thailand includes several limitations. Physical security is the key issue when making journeys to schools and universities and the destruction of physical buildings also poses concrete limitations to existing room based learning in the affected area. With this phenomenon, the accessibility to physical room based class is problematic and limited. In contrast, the accessibility to mobile networks is getting wider; accessibility to mobile devices is also getting cheaper and easier along the time, thus the investigation on how mobile learning could benefits the learners should be conducted. Consequently the research objectives were constructed which are (1) to estimate the current situation in the four southernmost provinces of Thailand, (2) to identify the limitations of existing room based learning affected by the unrest situation in the area, (3) to explore information from government sources and published papers about mobile technology used in the southernmost provinces of Thailand and (4) to construct initial guidelines and recommendations framework when using mobile technology as a learning environment in the school system of the southernmost provinces of Thailand. In order to achieve these objectives, the literature analysis, focus groups, and semi-structured interviews were conducted. From the analysis of the data collected, it was found that the utilization of mobile technology in the four southernmost provinces of Thailand currently still far behind the idea of what mobile learning technology should be. There are several limitations and thus certain guidelines for the mobile learning implementation should be produced.
\end{abstract}

Keywords: mobile learning, ubiquitous computing, pervasive computing, mobile device

\section{Introduction}

\subsection{Current Conflict Situation in the Four Southernmost Provinces of Thailand}

Deep South Watch database of the southern situation, Prince of Songkla University, Pattani Campus, indicates that the unrest situations in southern provinces of Thailand from January 2004 until August 2011 for a period of seven years have caused the violence in total about 11,074 events which contributed to the deaths and injuries combined, approximately 12,841 victims with 4,846 deaths and 7,995 injuries (Jitpiromsri, 2011). If we are monitoring the situation closely and continue to adhere, it was found that unrest in the southern provinces is the pattern of violence that erupted continuously and jump higher sometimes. This pattern of violence reflects the representation of endless violence, previous statistics indicates that there is violence in the high-low swing up and down all along (Jitpiromsri, 2011). It can be said that this is a continuation of the dynamics of the situation that should be remarkably watched carefully.

Among various education problems in southern Thailand, the violence and conflicts have tremendously affected the education system in the area. According to Human Rights Watch (2010), the education system was affected by the violence in three ways which are (1) attacks and threats to teachers, (2) the occupation of the premises of the school by the security forces and (3) the attack on public schools of the insurgents. The attacks and threats to teachers directly affect the education system, southern Thailand is one of the most dangerous places in the world, not only for teachers but also executives, drivers and school janitors have died from the attacks of the insurgents. In the southern provinces between January 2004 and the first week of September 2010, at least 108 teachers and other 27 educational personnel were killed in the attacks which are expected to be the treat of a group of 
insurgents (Human Rights Watch, 2010). As a result, many teachers live in fear every day. There are many teachers have asked the government to move out to teach outside of the southern area.

\subsection{Problem Statement}

Since January 2004 the four southernmost provinces of Thailand which are Pattani, Yala, Narathiwas and Songkhla, were severely damaged by the unrest situation. Unfortunately, this situation is not much positively improved until now (2013, July). Literally, to retain the quality of the education system in the four southernmost provinces of Thailand is very difficult. Physical security is the key issue when making journeys to schools and universities. Furthermore, the destruction of physical buildings in the unrest area also pose concrete limitations to existing room based learning in the affected areas. With this phenomenon, the accessibility to physical room based class is problematic and limited. The results of this phenomenon tremendously affect the learners in terms of learning achievements and the accessibility to physical room based class is problematic and limited. Many students are not able to read or write properly when they finished their primary school and the national averages of student achievement scores in all subjects are below and under standard comparing to other Thai regions.

In contrast, the accessibility to mobile networks is getting wider; accessibility to mobile devices is also getting cheaper and easier along the time. Currently the use of mobile learning provides essential benefits to learners in terms of any time-anywhere utilization.

Thus the investigation on how mobile technology and mobile learning has been used as an educational tool in the school system in the southernmost provinces of Thailand should be examined and conducted. Consequently the research objectives were constructed which are (1) to estimate the current situation in the four southernmost provinces of Thailand, (2) to identify the limitations of existing room based learning affected by the unrest situation in the area, (3) to explore information from government sources and published papers about mobile technology used in the southernmost provinces of Thailand and (4) to construct initial guidelines and recommendations framework when using mobile technology as a learning environment in the school system of the southernmost provinces of Thailand.

\subsection{Mobile Learning Overview}

Research of Mobile learning has been studied over two decades ago and spread in many parts of the world. Some earlier projects started in European countries leading by United Kingdom (Dias et al., 2008) for examples HandLer (Sharples, 2000; Sharples et al., 2002), MOBILearn (Sharples et al., 2005), and M-Learning (m-Learning, 2005). Many researchers have described perspectives of mobile learning in different point of views.

Quinn (2000) has defined Mobile learning as it is the intersection of mobile computing and e-learning comprising of accessible resources wherever you are, strong search capabilities, rich interaction, powerful support for effective learning, and performance-based assessment.

According to Nyiri (2002), Mobile learning is fundamentally e-learning delivered through mobile computational devices such as Palms, Personal Digital Assistants (PDA), Pocket PCs, smart phones, digital cell phones, and any other handheld devices. Moreover, the use of mobile devices with the wireless network technology flourishes mobile learners to get conveniences, expediency and immediacy of mobile learning in appropriate time and accessing the appropriate learning contents (Chen, 2003).

Sharples et al. (2005) also states that there is a need to re-conceptualize learning for the mobile age, to recognize the essential role of mobility and communication in the process of learning, and also to indicate the importance of context in establishing meaning, and the transformative effect of digital networks in supporting virtual communities that transcend of age and culture. In a project called 'MOBIlearn' which is a worldwide European-led research and development project exploring context-sensitive approaches to informal, problem-based and workplace learning by using key advances in mobile technologies, the team contributed several recommendations for mobile learning. The project contained several working groups which studied for both levels of learning, young and adults. As part of the process of developing a theory of mobile learning, the core members of the MOBIlearn European project held a reflection session during its final meeting in January 2005 , to discuss what is distinctive about mobile learning and "what do they know now that they didn't at the start of the project". The conclusion findings from the final reflection session about mobile learning, illustrating the collective perception of twelve research leaders after 30 months of the project are as follows:

- It is the learner that is mobile, rather than the technology.

- Learning is interwoven with other activities as part of everyday life. 
- Learning can generate as well as satisfy goals, it can be initiated by external goals or a learner's needs and problems.

- The control and management of learning can be distributed across learners, guides, teachers, technologies, and other resources in the world.

- The learning context is constructed by learners through interaction between learners and their environment.

- Mobile learning can both complement and conflict with formal education.

- Mobile learning raises deep ethical issues of privacy and ownership. For example in some mobile learning systems, parents are able to trace the development of their children's learning anytime. While on some systems, parents are able to trace the location of their children.

At technology driven age, education has been re-conceptualized around the construction of knowledge through information processing, modeling, interaction and technology utilization. Through mobile technology, learners may come to visualize of education as conversation in context, enabled by continual interaction through and with personal and mobile technology (Sharples et al., 2005). However Japanese researchers seemed to define mobile learning as pervasive and ubiquitous learning emphasising that mobile devices often are applied in learning situations taking place at a place directly related to object of learning. The concept of pervasive learning or ubiquitous learning is "always on" education which is available 24 hour a day, 7 days a week, anywhere, at anytime (Dias et al., 2008).

From the literature review the definitions of mobile learning seems to be similar and can be summarised that mobile learning should be portability, mobility, accessibility, adaptability, interactivity, sociality and wireless. Mobile learning can be useful when applying in the implementation of mobile learning for school children in the conflict situation. For example, in the conflict situation, the schools in the area are often closed due to the violence, it could be useful if children can learn and interact with partners and teachers through mobile learning technology.

\subsection{Mobile Learning in Diverse Areas}

Mobile learning have been applied in diverse areas such as in geography field work (Theng et al., 2007), rural area (Kumar et al., 2010), environmental restoration site (Rogers et al., 2009), and a trip to an archaeological park (Costabile et al., 2008). Theng et al. (2007) implemented Mobile G-Portal, a group of mobile devices as learning assistant tools supporting collaborative sharing and learning for geography fieldwork. From their study, Theng et al. (2007) suggested that digital libraries could go beyond desktop applications, providing "just-in-time/just enough" information through mobility of new digital devices such as PDAs for more effective learning and teaching. Kumar et al. (2010), on the other hand, carried out participant observations to identify the opportunities in students' everyday lives for mobile learning by conducting a 26-week study to investigate the extent to which rural children will voluntarily make use of cell phones to access educational content. Their study showed a reasonable level of academic learning and motivation. They highlighted that cell phones are a perfect vehicle for making educational opportunities accessible to rural children in places and times that are more convenient than formal schooling.

Rogers et al. (2009) studied another application of mobile learning in a different area, their research is concerned with how mobile devices can be used to engender collaborative sense making activities during scientific tasks when measuring the effects of different planting methods for an environmental restoration site. The study was conducted at ecological restoration of urban riverbanks which also serves as a learning site for a variety of students. From their study, they concluded that their research has shown how mobile devices can be used by collaborative teams to switch between task-based and sense making activities, moving between their experiences of the physical environment and higher level ideas and abstractions, provided the workload is not too high and the digital information can readily be shared among the team. Costabile et al., (2008) compared the experience of playing the learning game with and without technological support at the archaeological park of Egnathia, in Southern Italy. This study demonstrated that no distraction was generated in the students by the technology and proved the effectiveness of the electronic version of the excursion-game as a learning technique. As a consequence, Costabile et al., (2008) addressed that e-learning can be regarded as equally valuable as traditional learning, provided that appropriate techniques are used, which are able to exploit the advantages of the technology and to engage and stimulate students.

Another interesting study in the school context was conducted by Passey (2010), the case study project involved two primary schools in a locality with high socioeconomic deprivation and one primary school located in a suburban area. The study presented an argument that implementing activities involving mobile technologies that 
offer benefits to learning requires an adoption of approaches and factors at a wide systemic level. The study also suggested that learning activities using mobile technologies can (and should) occur within learning settings that constitute the foundation of a wide system, including both home and school (informal to formal) elements From his study, Passy (2010) proposed an implementation framework that accommodates appropriate practices within this wide context, it highlights the need for cultural and political factors to be involved at earlier as well as later implementation stages if wide success is to be accomplished.

With the substantial achievements of mobile learning in diverse areas as discussed earlier from many studies, it motivates that the investigation on how to use mobile learning in the unrest situation should be examined to enhance students' learning and create a new, innovate learning channel for our learning society.

\subsection{Guidelines for Mobile Learning}

We investigated the set of guidelines that should be produced when using mobile learning in general and to be modified for future utilization in the affected area. Vavoula et al. (2007) suggested the set of guidelines for learning, teaching and tutoring. This set of guidelines include 10 guidelines which are costs, usability-systems design, choice of technology, roles, equipment management, support for teachers, admin, collaboration, services/applications, and security/privacy. The description of each guideline is explained in Table 1. From the set of guidelines presented in Table 1, the important guidelines that should be addressed in the case of the four southernmost provinces of Thailand should be identified, additional adaptation are needed to comply with the learning needs in the affected area.

Table 1. Description for each guideline

\begin{tabular}{|c|c|c|c|}
\hline Number & Title & Description & Audience \\
\hline 1 & Costs & $\begin{array}{l}\text { Research the cost model for infrastructure, technology } \\
\text { and services }\end{array}$ & Institutions \\
\hline 2 & $\begin{array}{l}\text { Usability-systems } \\
\text { design }\end{array}$ & $\begin{array}{l}\text { Observe the usability requirements of all those involved } \\
\text { in the use of the system In any way (learners, teachers, } \\
\text { content creators) to assure system acceptability }\end{array}$ & $\begin{array}{l}\text { System designer/ } \\
\text { usability } \\
\text { engineers }\end{array}$ \\
\hline 3 & $\begin{array}{l}\text { Choice } \\
\text { technology }\end{array}$ & $\begin{array}{l}\text { Assess suitability of device / technology for learning task, } \\
\text { and examine advantages and disadvantages of each } \\
\text { technology before making a decision on which one to use }\end{array}$ & $\begin{array}{l}\text { Institutions, } \\
\text { teachers, system } \\
\text { designers }\end{array}$ \\
\hline 4 & Roles & $\begin{array}{l}\text { Assign or assume necessary roles for initiating and } \\
\text { supporting mobile learning }\end{array}$ & $\begin{array}{l}\text { Institutions, } \\
\text { decision makers, } \\
\text { staff, users, } \\
\text { beneficiaries of } \\
\text { mobile learning }\end{array}$ \\
\hline 5 & $\begin{array}{l}\text { Equipment } \\
\text { management }\end{array}$ & $\begin{array}{l}\text { Develop procedures and strategies for the management of } \\
\text { equipment when it is provided by the institution }\end{array}$ & $\begin{array}{l}\text { Institutions/ } \\
\text { teachers }\end{array}$ \\
\hline 6 & Support for teachers & $\begin{array}{l}\text { Provide training and (ongoing) technical support to the } \\
\text { teachers to enable them to use mobile technologies to } \\
\text { enhance current, and to enable new instructional activities }\end{array}$ & $\begin{array}{l}\text { Institutions, } \\
\text { educational } \\
\text { authorities }\end{array}$ \\
\hline 7 & Admin & $\begin{array}{l}\text { Consider the use of mobile technologies for student } \\
\text { administration tasks }\end{array}$ & $\begin{array}{l}\text { Institutions, } \\
\text { teachers }\end{array}$ \\
\hline 8 & Collaboration & $\begin{array}{l}\text { Consider the use of mobile technologies to support } \\
\text { collaborative and group learning }\end{array}$ & Teachers \\
\hline 9 & Services/applications & $\begin{array}{l}\text { Discover and adopt suitable applications that match the } \\
\text { needs of your specific classroom and map directly to your } \\
\text { curriculum needs }\end{array}$ & Teachers \\
\hline 10 & And security/privacy & $\begin{array}{l}\text { Security / privacy Description Ensure security and } \\
\text { privacy for the end users }\end{array}$ & System designers \\
\hline
\end{tabular}




\section{Method}

In conducting this research project, the qualitative research was carried out with 3 research methods which are (1) documentary research, (2) focus groups and (3) semi-structured interviews. The details of each research method will be presented next.

\subsection{Research Methodology}

As stated earlier that this research project was conducted under the qualitative research approach with the combination of 3 research methods which are documentary research, focus groups and semi-structured interviews. The documentary research was conducted to gain the preliminary findings while the focus groups and semi-structured interviews were conducted to confirm and gain more comprehension of:

- Current situation in the four southernmost provinces of Thailand.

- The limitations of room based learning in the affected areas.

- Mobile technology used in the four southernmost provinces of Thailand.

\subsubsection{Focus Groups}

In this study, apart for the documentary research which aimed to obtain the preliminary findings, the focus group was also conducted to confirm and gain additional understanding of current situation in the four southernmost provinces of Thailand, the limitations of room based learning in the affected areas and mobile technology used in the four southernmost provinces of Thailand. The focus groups were conducted by conducting the panel interviews with primary and secondary school teachers.

The focus group is simply panel interview, in this study the focus group consisted of 12 participants from the primary school teachers. During the focus group sessions the interviewer asked the prepared questions to the panel of participants, each participant could then provide the data based on the questions asked. The questions were open and flexible, the key words in the questions were used to guide the panel interview sessions. The questions were flexible as they could be adapted in order to make them suitable with each interviewee who was from different context, background and situations. The mentioned technique aimed to obtain the data from different dimensions as well as the facts in the real situations. It also aimed to obtain both depth and broad data.

\subsubsection{Semi-Structured Interviews}

The semi-structured interviews were also conducted to confirm and gain additional understanding of current situation in the four southernmost provinces of Thailand, the limitations of room based learning in the affected areas and mobile technology used in the four southernmost provinces of Thailand. The semi-structured interviews dealt with local leaders, education service providers and government officials, the semi-structured interviews were conducted with this group of samples as it was impractical to bring these participants met in one occasion. The semi-structured interviews were conducted with guided interview questions. The questions for the semi-structured interviews were similar to questions for the focus group.

\subsection{Samples}

The samples for data collection included teachers from primary schools, local leaders, education service providers and government officials. The samples selection technique is the purposive random, in which the researchers purposely selected the samples in order to obtain the data from qualitative research approach. The data can be processed to investigate the findings. The selections of samples for the focus groups and semi-structured interviews will be explained next.

\subsubsection{The Samples for the Focus Groups}

The samples for the focus groups were selected to provide data and information on current situation in the four southernmost provinces of Thailand, the limitations of room based learning in the affected areas and mobile technology used in the four southernmost provinces of Thailand. The teachers were selected as samples for the focus group as those teachers are the group which are directly impacted by the school system violation, thus they know well about the issues affected to the school system. The focus group samples involved 12 participants from primary school teachers of the four southernmost provinces.

\subsubsection{The Samples for the Semi-Structured Interviews}

This group of samples was selected to provide the same data and information as provided by the focus group, which are current situation in the four southernmost provinces of Thailand, the limitations of room based learning in the affected areas and mobile technology used in the four southernmost provinces of Thailand. The samples for semi-structured interviews were selected from local leaders, education service providers and 
government officials from the southernmost provinces, there are 6 respondents participated in the semi-structured interview. Local leaders, education service providers and government officials were selected with the following reasons:

- As community leaders, they know well about the current situation in the affected area.

- Education service providers and government officials know well about the limitations of room based learning in the affected areas and mobile technology used in the four southernmost provinces of Thailand as they are parts of the team involved in the implementation of mobile device utilization in Thai school system.

\subsection{Construction of the Questions for Focus Groups and Interviews}

The questions for the focus groups and semi-structured interviews were prepared by considering the issues needed to tackle. These are the current situation in the four southernmost provinces of Thailand, the limitations of room based learning in the affected areas and the mobile technology used in the four southernmost provinces of Thailand. The questions prepared are semi structured and opened. As the questions are opened so they are flexible, the key words in the questions were used to guide the interviews. With the flexible questions, they can be adapted to make them suitable with each interviewee who is from different context, background and situations The mentioned approach aimed to obtain the data from different dimensions as well as the facts in the real situations. The interviews aimed to obtain both depth and broad data.

After the questions were initially constructed by the researchers, the questions were then reviewed and validated in terms of clarity and content accuracy by the experts to ensure that these questions were complied with the research questions and objectives. After that the questions were tested with the some sample respondents who have the same background with the real respondents to ensure that the questions were appropriate, accurate and clear. Before the interviews, the questions were given to the respondents 2 weeks earlier to provide familiarity to the questions.

\subsection{Data Collection}

The data for this study were collected from three main sources which are (1) Documentary research (2) Focus group interviews and (3) Semi-structured interviews. For the documentary research, the data were collected from the related literature from the published paper, related organization in the conflict area, and government sources. For the focus group and semi-structured interview, the researchers collected the data by taking notes the interview contents. The interview sessions were also recorded with and audio recorder with the interviewers' permission, these audio records can be used to cross-check the data collected after the interview sessions.

\subsection{Data analysis}

The data collected from the documents, focus groups and semi-structured interviews were analyzed by firstly considering the major themes or major patterns, the major themes were then separated into sub-themes and categories consequently. Apart from the analysis at the end of the data collection, during the interview sessions, the researchers also conducted the reflecting process during the data collection. The reflecting process was used to make sure that the data obtained was clear and precise and to ensure that the research process was intense and rigor.

\section{Results}

From the analysis of the data collected, it was found that the utilization of mobile learning in the four southernmost provinces of Thailand currently still far behind the idea of what mobile learning technology should be. We found many limitations on conducting and deploying M-learning in the southernmost provinces of Thailand which is briefly presented in Table 2 . 
Table 2. Limitation of the four southernmost provinces of Thailand

\begin{tabular}{|c|c|}
\hline Limitation & Description \\
\hline Current unrest situation & $\begin{array}{l}\text { Shooting of teachers, soldiers and security guards happen in a regular basis and the } \\
\text { violence level is getting higher and more aggressive that directly affects the school } \\
\text { education. The journey between home and school cannot be done in a regular time } \\
\text { and manners. The schools are often shut down for security reason and most of } \\
\text { school finished their teaching at earlier time for safety reason. }\end{array}$ \\
\hline $\begin{array}{l}\text { Utilization of mobile } \\
\text { learning technology }\end{array}$ & $\begin{array}{l}\text { The tablet PCs are provided to yearl primary school students by the government but } \\
\text { the specific tables equipped with electric adaptor for tablet learning are not yet } \\
\text { provided. Accessible to data network is blocked since the focus is on offline } \\
\text { contents. Wireless networks in the area are not yet widely coverage. The } 3 \mathrm{G} \text { mobile } \\
\text { network which is one of the true widely coverage data networks are still in the very } \\
\text { beginning implementation in the affected area. }\end{array}$ \\
\hline $\begin{array}{l}\text { Teachers and } \\
\text { administration staffs }\end{array}$ & $\begin{array}{l}\text { Currently, there are not enough teachers for many schools and for the existing } \\
\text { teachers, they have to be much aware of their own safety, resulting in paying less } \\
\text { attention to their students. Another issue is that the teachers who are appointed to } \\
\text { take responsible on mobile learning lessons have no ideas and no experiences on } \\
\text { how to conduct the teaching. Teachers have no sufficient guidelines and training for } \\
\text { conducting the mobile learning lessons. }\end{array}$ \\
\hline Students & $\begin{array}{l}\text { Students are not able to read the English instructions and even the Thai itself is still } \\
\text { problematic. Most students use Malay dialogue in daily life that causes problems in } \\
\text { reading and understanding Thai instructions and learning contents. }\end{array}$ \\
\hline Parents & $\begin{array}{l}\text { Parents have little education and have no ideas about using mobile learning in the } \\
\text { education system. }\end{array}$ \\
\hline Domain contents & $\begin{array}{l}\text { Domain contents are not well designed to support learning for example yearl } \\
\text { primary school students have to read long texts and instructions, the font size is too } \\
\text { small forcing students to scroll down to get details while some students are not able } \\
\text { to use devices properly. The students in this level just start to learn how to spell and } \\
\text { thus they are not able to read long instructions. Another problem is that the rows are } \\
\text { too narrow, and the contents are overloaded. Even the zoom option is available, but } \\
\text { it is still problematic as the students at this level are not able to assess the length and } \\
\text { dimension correctly. Existing domain contents do not include interactivity between } \\
\text { learners or between learners and teachers. Additional learning materials and } \\
\text { techniques to support mobile learning are not yet provided. }\end{array}$ \\
\hline
\end{tabular}

From the limitations that we found, it can be summarised as follows: 1) lacking of experienced teachers for mobile learning, 2) lacking of good teaching administrations and technical support on mobile learning, 3) lacking of training and tutoring for teachers to manage and facilitate students inside and outside classrooms, 4) no various contents and activities to individual learning needs, 5) lacking of learning resources and supplementary contents, 6) reading and language capability barrier, 7) no collaboration between learners, 8) no participation from parents, 9) curriculum planning for teachers 10) lacking of evaluation pattern for contents, teachers and learners 11) insufficient physical environment establishment (screen size, weight, battery life, network availability) and 12) perception of teachers, learners and parents toward mobile learning technology is still mistaken. From these limitations we suggested that certain guidelines should be produced and contributed to relevant stakeholders, we proposed the set of guidelines as illustrated in Table 3. 
Table 3. Recommended guidelines for the four southernmost provinces of Thailand

\begin{tabular}{|c|c|c|c|}
\hline No. & Expected M-learning Characteristics in the Area & $\begin{array}{l}\text { Recommended } \\
\text { Guidelines/Activities }\end{array}$ & $\begin{array}{l}\text { Relevant } \\
\text { Users }\end{array}$ \\
\hline 1 & $\begin{array}{l}\text { M-learning curriculum should be carefully } \\
\text { designed to support M-learning anywhere-anytime } \\
\text { paradigm. }\end{array}$ & $\begin{array}{l}\text { G1: Guidelines for M-learning } \\
\text { curriculum }\end{array}$ & $\begin{array}{l}\text { Policy makers, } \\
\text { Teachers, }\end{array}$ \\
\hline 2 & $\begin{array}{l}\text { Proper teaching plan should be prepared for } \\
\text { M-learning class. }\end{array}$ & $\begin{array}{l}\text { G2: Guideline for M-learning } \\
\text { teaching plan }\end{array}$ & Teachers \\
\hline 3 & $\begin{array}{l}\text { Various contents and activities tailored to individual } \\
\text { learning needs should be provided. }\end{array}$ & & \\
\hline 4 & $\begin{array}{l}\text { Learning resources and supplementary contents } \\
\text { should be provided. }\end{array}$ & $\begin{array}{l}\text { G3: Guidelines for M-learning } \\
\text { content identification }\end{array}$ & $\begin{array}{l}\text { Teachers, } \\
\text { Developers }\end{array}$ \\
\hline 5 & Collaboration between learners should be guided. & & \\
\hline 6 & Teachers, learners and parents should be assessed. & $\begin{array}{l}\text { G4: Guidelines for M-learning } \\
\text { evaluation }\end{array}$ & $\begin{array}{l}\text { Teachers, } \\
\text { learners, } \\
\text { developers }\end{array}$ \\
\hline 7 & $\begin{array}{l}\text { All stake-holder should understand that M-learning } \\
\text { is not to replace but to enhance traditional } \\
\text { classroom activities. It should include collaboration } \\
\text { and interaction between learners. }\end{array}$ & $\begin{array}{l}\text { G5: Guideline for perceptions } \\
\text { and roles }\end{array}$ & $\begin{array}{l}\text { Policy makers, } \\
\text { Teachers, }\end{array}$ \\
\hline 8 & $\begin{array}{l}\text { Parents should play an essential role to support } \\
\text { M-learning. }\end{array}$ & & \\
\hline 9 & $\begin{array}{l}\text { Reading and language capability should be } \\
\text { considered to provide usability contents/system. }\end{array}$ & $\begin{array}{l}\text { G6: Guidelines for M-learning } \\
\text { usability design }\end{array}$ & $\begin{array}{l}\text { Teachers, } \\
\text { developers }\end{array}$ \\
\hline 10 & $\begin{array}{l}\text { Background/belief of learners should be considered } \\
\text { to provide appropriate contents/applications. }\end{array}$ & $\begin{array}{l}\text { G7: Guidelines for additional } \\
\text { services/applications }\end{array}$ & $\begin{array}{l}\text { Teachers, } \\
\text { developers }\end{array}$ \\
\hline 11 & $\begin{array}{l}\text { Choice of technologies should be guided and } \\
\text { M-learning infrastructure should be provided. }\end{array}$ & $\begin{array}{l}\text { G8: Guidelines for choice of } \\
\text { technology and infrastructure } \\
\text { establishment }\end{array}$ & $\begin{array}{l}\text { Mobile network } \\
\text { Operators, } \\
\text { school } \\
\text { management }\end{array}$ \\
\hline 12 & $\begin{array}{l}\text { The guidelines for using the relevant equipment } \\
\text { should be provided to learners and teachers. }\end{array}$ & $\begin{array}{l}\text { G9: Guidelines for equipment } \\
\text { management }\end{array}$ & $\begin{array}{l}\text { Teachers, } \\
\text { learners }\end{array}$ \\
\hline 13 & Experienced teachers should be provided. & Training for teachers by using & Teachers \\
\hline 14 & Training for teachers should be provided. & os imnlemented & \\
\hline
\end{tabular}

\section{Discussion}

The following sub-sections propose the guideline introductions/explanations to be used for the production of detailed guidelines later on, these guidelines are based on the set of guidelines suggested in Table 3. Each sub-section identifies what issues should be addressed and included in the guidelines.

\subsection{Guidelines for M-Learning Curriculum}

M-learning curriculum is a starting point for M-learning implementation. It should contain a clear picture of the concept of M-leaning; what they are using for, which subjects/contents should be provided and how to deliver those subjects/contents. Essentially, the curriculum should clearly define that for each content, the learners are required to know (acquisition of domain knowledge), to do (develop skills with M-learning practice) or to understand (comprehend the role and impact of the domain knowledge in relation to the application context). M-learning curriculum should be carefully designed to support M-learning anywhere-anytime paradigm. These guidelines are for education policy makers, education management and teachers. 


\subsection{Guidelines for M-Learning Teaching Plan}

Guidelines to support teachers should be produced as a mobile learning administration handbook. This handbook could assist teachers in teaching students inside and outside the classrooms. The guidelines in the handbook should include:

- How to allocate time for M-learning.

- How to introduce the students in the classroom.

- How to control and monitor students during learning with in an M-learning environment.

- How to interact with students inside and outside classrooms.

- An issue that should be aware is that the children's utilization of their physical muscle, overuse of tablet PCs may result in lacking of muscle utilization and cause long term muscle development problem. Therefore the time allocation for the M-learning has to be settled and restricted to balance the utilization of technology tools and physical muscle.

\subsection{Guidelines for M-Learning Content Identification}

Content identification is an essential task for M-learning implementation, it could ensure that learners are able to learn what they are capable of. The contents for M-learning are not only the main stream subjects such as Math, Thai, and etc., but it should cover various contents and activities tailored to individual learning needs and collaboration between learners. Learning resources and supplementary contents should also be provided. These guidelines are for education policy makers, education management, content creators and teachers.

\subsection{Guidelines for M-Learning Evaluation}

Evaluation and assessment is an essential process in learning, we suggest that both process and products should be assessed. The process here is composed of the way the learners learn and the contents the use in learning. While the product in this case is the learners' ability after they have learnt with M-learning technology. The evaluation pattern and steps for both process and products in M-learning implementation should be provided. These guidelines are for teachers, learners, and content developers.

\subsection{Guidelines for Perceptions and Roles}

In terms of perceptions, all stake-holder should understand that M-learning is not to replace but to enhance traditional classroom activities. It should include variety of activities tailoring to learners' needs and background as well as collaboration and interaction between learners. It should also comply with the anywhere-anytime paradigm of M-learning. In terms of roles, teachers alone are not able to ensure the successfulness of mobile learning in the area. We suggest that another party who play an essential role in looking after these students is their parents. Thus the guideline for the parents in observing and controlling of their children in utilizing the mobile learning at home should be implemented. This guideline should be brief, straightforward and not time consuming to learn. Parents' role are not to teach the lessons for their children but to balance the utilization of this learning technology tool with traditional learning methods, social and life skills acquisition.

\subsection{Guidelines for Content Usability Design}

In general, the usability design principles for should be used to guide the development of M-learning contents, [3] suggested that the usability design issues include learnability, efficiency, memorability, errors and satisfaction:

- Learnability: How easy is it for users to accomplish basic tasks the first time they encounter the design?

- Efficiency: Once users have learned the design, how quickly can they perform tasks?

- Memorability: When users return to the design after a period of not using it, how easily can they reestablish proficiency?

- Errors: How many errors do users make, how severe are these errors, and how easily can they recover from the errors?

- Satisfaction: How pleasant is it to use the design?

However, another aspect of the usability design in this case is much related to the limitation in terms of reading capability of learners in the affected area. Reading capability plays an essential role in the success of mobile learning in the affected area. As it was found that students in the area are not able to read the instructions of the mobile contents well, the problem exists for both Thai and English. Students in this level just start to learn how to spell and read and thus they are not able to read long instructions. The contents which include images and sounds such as Math, Thai and Music subjects are appropriate and practical for this learning level as they do not 
contain long instructions and text information. These guidelines are for content developers and teachers.

\subsection{Guidelines for Additional Services/Applications}

These guidelines are for content developers and teachers. The implementation of mobile learning in the affected would be much more useful with additional services and applications specific to the students' needs. These are because the students in this area have two different characteristics from other parts of the country, these are the language and the belief. In terms of the language, the students in the area use Malay dialogue in everyday life, they do not use Thai outside the class rooms like other parts of the country. One of the value added service to support this characteristic is that the Malay subject should be introduced and implemented, it should be one of the subjects to be studied in the area. This is also one of the urgent strategies that should be realized by the education policy maker in preparing young citizen of Thailand to enter the Asean Economic Community (AEC) protocol in 2015. The Malay or Malayu language is the one that are widely used in the Asean countries including Malaysia, Indonesia, Brunei, and some parts of Philippines, it was used by about 300 million people of the Asean Community. If this happens, the students in the area will be equipped with more language skills and be more ready to enter the AEC with competitive skills.

Another characteristic of students in the area is drawn upon their belief, they are Muslims who belief in Islam, in which it is different from the students in other parts of the country who are mostly Buddhists. This is an important characteristic that educator in Thailand should pay full attention, the value added for this characteristic is to provide additional contents for students to learn more about their belief, their practice and their true Islamic concepts. Additional contents may emphasize peace in Islam, the contents which guide students to learn about peace in Islam should be added to promote peace process and multi-cultural living in this conflict area. These additional contents should be provided through video and animation formats which are easily accessed with the tablet and essentially it is in the interests of students in this age.

\subsection{Guidelines for Choice of Technology and Infrastructure Establishment}

The technologies involved with mobile learning in the area are hardware, software and networking. It was found that the software equipped with hardware has no major problems, while the hardware and networking are still problematic. In terms of hardware, the problem found from the data collection is that the 7 inches screen size tablet could display too small texts for students in this level and the rows are too narrow. Even the zoom option is available but it is still problematic as the students at this level are not able to assess the length and dimension correctly. The possible solution for this problem is to consider the bigger screen size tablet PCs, the bigger screen size tablets with 8.9 or 10 inches should be considered. Another problem in the hardware aspect is that the appropriate rooms for tablet utilization are still unavailable, the existing rooms have no electric socket for tablet charging therefore the tablet utilization is still limited.

For the network technology, we suggest that mobile phone network should be provided for the affected area. Currently, the mobile phone networks in the area are still very limited. The $3 \mathrm{G}$ network technology is not yet available in most area. In Thailand the $3 \mathrm{G}$ networks are only available in the large city area, it is unavailable in the rural area. If this $3 \mathrm{G}$ technology is widely available, certain opportunities for mobile learning in the area will be very much improved. In order to make this happen, the government and the mobile phone network operators have to be seriously involved with this action. These guidelines are for education service management, government and mobile network operators.

\subsection{Guidelines for Equipment Management}

The tablet PCs are one of specific learning tools that require proper care and management. The guidelines for using the tablet should be provided to students. The time management policy should also be implemented. Essentially the safety practice to prevent harms or injuries from the utilization of the electronic tools should be guided. The proper plan for services and repairs of the tools are also needed maintain the tablets. Furthermore, the effects of mobile network wave signal should also be studied in terms of health effects, then the proper use of mobile network should be suggested to promote safety learning. These guidelines are for teachers, learners and IT support staff.

\section{Conclusion}

From the findings in this study we found that the limitations of the mobile learning implementation in the four southernmost provinces of Thailand are perception of education service providers, teachers, learners and parents toward M-learning technology is still mistaken, lacking of good teaching curriculum and teaching plan, lacking of experienced teachers for mobile learning, lacking of evaluation pattern for teachers, learners and parents, lacking of training and tutoring for teachers to manage and facilitate students inside and outside classrooms, no 
various contents and activities to individual learning needs, lacking of learning resources and supplementary contents, reading and language capability barrier, no consideration of learners' background and belief, no collaboration between learners, too little participation from parents, and insufficient physical environment establishment.

With these limitations in mind, we suggested that essential guidelines should be produced to overcome the found weaknesses. We then recommended lists of guidelines that should be produced to ensure the success of the mobile learning implementation in the four southernmost provinces of Thailand. These guidelines are G1: Guidelines for M-learning curriculum, G2: Guideline for M-learning teaching plan, G3: Guidelines for M-learning content identification, G4: Guidelines for M-learning evaluation, G5: Guideline for perceptions and roles, G6: Guidelines for M-learning usability design, G7: Guidelines for additional services/applications, G8: Guidelines for choice of technology and infrastructure establishment, and G9: Guidelines for equipment management. We also recommended that all teachers should be trained by using the guidelines implemented. Then in section 4, we have proposed the initial guidelines which identify key issues that should be addressed in the specified set of guidelines.

\section{Acknowledgements}

We would like to extend our thanks and gratitude to Faculty of Communication Sciences and Prince of Songkla University for the financial and grateful support. We also thank you all individuals involved in the establishment of this research project.

\section{References}

Chen, Y. S., Kao, T., \& Sheu, J. P. (2003). A mobile learning system, for scaffolding bird watching learning. Journal of Computer Assisted Learning, 347-359. http://dx.doi.org/10.1046/j.0266-4909.2003.00036.x

Costabile, M. F., Angeli, A. D., Lanzilotti, R., Ardito, C., Buono, P., \& Pederson, T. (2008, April 5-10). Explore! Possibilities and Chanlenges of Mobile Learning. Paper presented at the CHI 2008 Proceeding of the twenty-sixth annual SIGCHI conference on Human factors in computing systems Florence, Italy.

Dias, A., Carvalho, J., Keegan, D., Kismihok, G., Mileva, N., Nix, J., \& Rekkedal, T. (2008). An Introduction to Mobile Learning. Retrieved September 13, 2011, from http://www.ericsson.com/ericsson/corpinfo/programs/the_role_of_mobile_learning_in_european_education /products/wp/socrates_wp1_english.pdf

Human Rights Watch. (2010). "The targets of both parties" Violence is going on with students, teachers and schools in the southern provinces of Thailand.

Jitpiromsri, S. (2011, October 5). The protracted violence in situations of chronic political instability after the 2011 election. Retrieved January 9, 2012, from http://www.deepsouthwatch.org/node/2305

Kumar, A., Tewari, A., Shroff, G., Chittamuru, D., Kam, M., \& Canny, J. (2010, April 10-15). An Exploratory Study of Unsupervised Mobile Learning in Rural India. Paper presented at the CHI 2010 Proceedings of the 28th international conference on Human factors in computing systems Atlanta, Geogia, USA.

M-Learning. (2005). M-learning project background. Retrieved June 30, 2008, from http://www.m-learning.org/archive/background.shtml

Nyiri, K. (2002, August 29-30). Towards a philosophy of m-learning. Paper presented at the Proceeding of the 1st IEEE International Workshop on Wireless and Mobile Technologies in Education (WMTE' 02), Vaxjo, Sweden.

Passy, D. (2010). Mobile Learning in School Contexts: Can Teachers Alone Make It Happen? Ieee Transactions On Learning Technologies, 3(1), 14. http://dx.doi.org/10.1109/TLT.2009.47

Quinn, C. (2000). M-Learning. Mobile, Wireless, In-Your-Pocket Learning. Retrieved March 10, 2012, from http://www.linezine.com/2.1/features/cqmmwiyp.htm

Rogers, Y., Connelly, K., Hazlewood, W., \& Tedesco, L. (2009). Enhancing learning: a study of how mobile devices can facilitate sensemaking. Personal and Ubiquitous Computing (2010), 14(2), 111-124.

Sharples, M. (2000). The Design of Personal Mobile Technologies for Lifelong Learning. Computers and Education, 34, 177-193. http://dx.doi.org/10.1016/S0360-1315(99)00044-5

Sharples, M., Corlett, D., \& Westmancott, O. (2002). The Design and Implementation of a Mobile Learning Resource. Personal and Ubiquitous Computing, 6, 220-234. http://dx.doi.org/10.1007/s007790200021 
Sharples, M., Taylor, J., \& Vavoula, G. (2005, February 2). Towards a theory of mobile learning. Retrieved December 18, 2011, from http://www.mlearn.org.za/CD/papers/Sharples/Theory/Mobile.pdf

Theng, Y. L., Tan, K. L., Lim, E. P., Zhang, J., Goh, D. H. L., Chatterjea, K., Chang, C. H., Sun, A., Han, Y., Dang, N. H., Li, Y., \& Vo, M. C. (2007, June 18-23). Mobile G-Portal Supporting Collaborative Sharing and Learning in Geography Fieldwork: An Empirical Study. Paper presented at the JCDL'07 Proceedings of the 7th ACM/IEEE-CS joint conference on Digital libraries Vancouver, British Columbia, Canada.

Vavoula, G. N., Lefrere, P., O'Malley, C., Sharples, M., \& Taylor, J. (2004). Producing guidelines for learning, teaching, and tutoring in a mobile environment. Paper presented at the 2nd IEEE International Workshop on Wireless and Mobile Technologies in Education (WMTE'04).

\section{Copyrights}

Copyright for this article is retained by the author(s), with first publication rights granted to the journal.

This is an open-access article distributed under the terms and conditions of the Creative Commons Attribution license (http://creativecommons.org/licenses/by/3.0/). 